\title{
An Evaluation of Sodium Ethyl Xanthate for the Froth Flotation Upgrading of a Carbonatitic Copper Ore
}

\author{
Mokgethwa Florence Meso, ${ }^{1}$ Abraham Adewale Adeleke, ${ }^{2 *}$ Peter Mendonidis ${ }^{1}$ \\ and Mosobalaje Oyebamiji Adeoye ${ }^{2}$ \\ ${ }^{1}$ Metallurgical Engineering, Vaal University of Technology, \\ Faculty of Engineering Sciences, Private Bag X021, \\ Vanderbijlpark, 1911, South Africa \\ ${ }^{2}$ Materials Science and Engineering, Faculty of Technology, \\ Off Ife-Ibadan Expressway, Obafemi Awolowo University, \\ Ile Ife, Osun State, 220002, Nigeria \\ *Corresponding author: adeadeleke@oauife.edu.ng
}

Published online: 25 August 2016

To cite this article: Meso, M. F. et al. (2016). An evaluation of sodium ethyl xanthate for the froth flotation upgrading of a carbonatitic copper ore. J. Phys. Sci., 27(2), 13-21, DOI: 10.21315/jps2016.27.2.2

To link to this article: http://dx.doi.org/10.21315/jps2016.27.2.2

\begin{abstract}
The carbonatitic Palabora copper ore was ground to the less energy intensive coarse size consisting of 45\% passing $75 \mu \mathrm{m}$ in a ball mill for $20 \mathrm{~min}$ and froth floated in a 4.5 l Denver cell at varying dosages of the highly selective sodium ethyl xanthate (SETX) at 200, 250, 300, 350 and $400 \mathrm{~g} / \mathrm{t}$. The concentrates were collected every $15 \mathrm{~s}$ at varying scraping times of 3, 7 and $10 \mathrm{~min}$. The results obtained showed that the highest recovery of $86.1 \%$ was obtained at the $300 \mathrm{~g} / \mathrm{t}$ SETX dosage with the lowest grade of $11.29 \%$, while the highest grade of $13.95 \%$ occurred at the lowest recovery of $78 \%$. The dosages of SETX used for the flotation was found to be generally higher than that of sodium iso-propyl xanthate (SIPX) used for another copper ore of non-carbonatitic origin. However, the successful flotation of the ore ground coarser than the conventional practice of $80 \%$ passing $75 \mu \mathrm{m}$ is economically significant in view of the potential power conservation obtainable.
\end{abstract}

Keywords: Ore, xanthate, dosage, froth flotation, concentrate

\section{INTRODUCTION}

Copper is most commonly present in the earth's crust as copper-iron-sulfide and copper sulfide minerals such as chalcopyrite $\left(\mathrm{CuFeS}_{2}\right)$, bornite $\left(\mathrm{CusFeS}_{4}\right)$ and chalcocite $\left(\mathrm{Cu}_{2} \mathrm{~S}\right)$. The concentration of these copper bearing minerals in an ore body is low and typical copper ores contain from $0.5 \%$ to $2 \% \mathrm{Cu}$ in open pit and 
underground mines. Pure copper metal is produced from these ores by concentration, smelting and refining. Copper is also found to a lesser extent in oxidised minerals such as carbonates, oxides, hydroxy-silicates and sulfates. ${ }^{1}$

The Palabora copper mine, operated by Palabora Mining Company (PMC), is located at Palaborwa in Limpopo province of South Africa. The company operates a single cluster of open-pit and underground mines producing mainly copper and other by-products. The original carbonate outcrop was a large hill known as Loolekop. The company also has a processing facility on site for the production of purified copper from mined copper ore and a vermiculite recovery plant. Its final copper product has two forms, namely copper cathode and copper rod. PMC's open cast mine is Africa's widest man-made hole at almost $2000 \mathrm{~m}$ wide. $^{2}$

The beneficiation of copper ores consists of isolating their copper minerals in high-grade concentrates. This involves crushing and grinding the ore to a particle size fine enough so that the mineral grains of the ore are by and large divided one from another and physical separation of the mineral particles by froth flotation to form separate, high grade concentrate of copper minerals occurs. Froth flotation is an indispensable technique for copper ore beneficiation. It is used to upgrade a copper ore to a concentrate by selectively floating copper-containing minerals rendered hydrophobic with a collector away from non-copper minerals that are hydrophilic. Collisions between air bubbles and the minerals which have been made hydrophobic will result in attachment between the bubbles and these minerals. ${ }^{3,4}$ The flotation method of ore beneficiation can only be applied to relatively fine particles. If the ground particles are too large, the adhesion between the bubble and the particle will be less than the particle's weight, making the bubble to drop its load. However, very fine grinding is costly and an optimum size range for successful and economic flotation has to be found. ${ }^{4}$

The xanthates are the most important collector for sulphides mineral flotation. They are prepared by reacting alkali hydroxide, alcohol and carbon disulphide. The most widely used xanthates are ethyl, isopropyl, isobutyl, amyl and hexyl xanthate. Sodium ethyl xanthate (SETX) is made up of the chemical formula $\mathrm{CH}_{3} \mathrm{CH}_{2} \mathrm{OCS}_{2} \mathrm{Na}$. As a collector, the selectivity of sodium ethyl xanthate is the strongest among xanthates. It is widely used in the preferential flotation of complex sulphides minerals. ${ }^{4,5}$

In this research, the performance of the highly selective SETX as a collector in the recovery of copper mineral values from a carbonatitic copper ore ground to a size consist much coarser than conventionally used for the flotation of copper ores was studied. 


\section{EXPERIMENTAL}

\subsection{Materials}

\subsubsection{Sample collection}

About $150 \mathrm{~kg}$ of Palabora copper ore was collected from the PMC. From the bulk sample, about $20 \mathrm{~kg}$ was taken for this study.

\subsubsection{Sample preparation}

The ore received from Palabora Mining Company comprised of lumps of different sizes and fine ore materials. The bulk sample was crushed in a jaw crusher and various size fractions were obtained ranging from $<2 \mathrm{~mm}$ to $>4 \mathrm{~mm}$. The various size fractions were screened using the $2 \mathrm{~mm}$ and $4 \mathrm{~mm}$ sieves. Three size fractions: $>4 ;<4 />2$; and $<2 \mathrm{~mm}$ were obtained. A representative mixture was then obtained from these fractions by coning and quartering.

\subsection{Methods}

\subsubsection{Ore milling}

A milling curve for the Palabora copper ore was first derived. Slurry consisting of about $1.5 \mathrm{~kg}$ of the ore in $750 \mathrm{ml}$ of water and loaded with about $7.2 \mathrm{~kg}$ of steel balls was formed in the ball mill drum. The prepared slurry was then ball-milled for $10 \mathrm{~min}$. The grinding balls were removed and the ground ore was emptied into a bucket. The milled sample was wet screened with a $75 \mu \mathrm{m}$ sieve. The wet screened sample residue was dried and weighed to determine the percentage that passed the $75 \mu \mathrm{m}$ sieve. The $>75 \mu \mathrm{m}$ residue was dried in an oven at $105^{\circ} \mathrm{C}$ for about $12 \mathrm{~h}$. The dried sample was split to get a representative sample that weighed about $300 \mathrm{~g}$ that was screened with a $300 \mu \mathrm{m}$ screen. The procedure described was repeated at 20,30, 40,50 and 60 min grinding times. The tests were carried out in duplicates. Using the data obtained, the milling curve was constructed (Figure 1). 


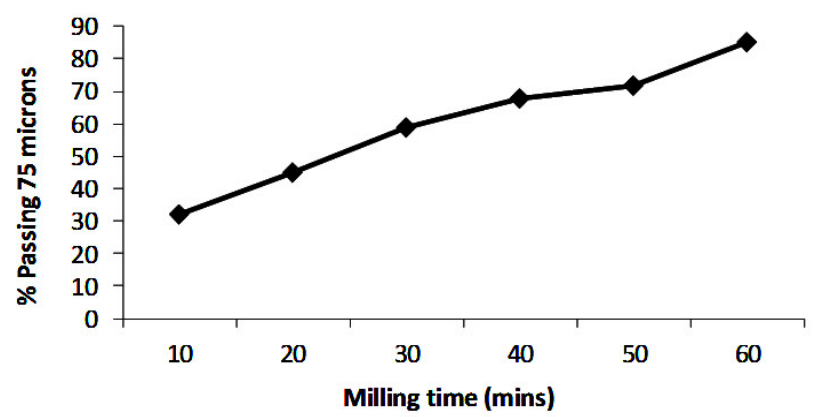

Figure 1: Milling curve for Palabora copper ore.

\subsubsection{Froth flotation}

The sodium ethyl xanthate collector was prepared in water at $60 \mathrm{~g} / \mathrm{t}$ strength. The prepared solution was thoroughly mixed for $5 \mathrm{~min}$ on the magnetic stirrer hotplate using a magnetic bar set to stir at $400 \mathrm{rpm}$ at $25^{\circ} \mathrm{C}$. Lime solution was also prepared to a $\mathrm{pH}$ of 11 . About $1.5 \mathrm{~kg}$ milled sample was poured into the 4.51 flotation cell and water was added to make up to the level of the cell. The flotation cell was placed in the base of the Denver flotation machine. The flotation impeller was lowered into the slurry and the concentrate collection pan was placed under the overflow lip of the cell. The agitator was started and the impeller was set to $1000 \mathrm{rpm}$. Lime and sodium ethyl xanthate collector were added with each given 2 min of conditioning time. Methyl isobutyl ketone was used as the frother. The air valve was opened to produce the frothing. The froth was then scraped across the top of the cell towards the overflow every $15 \mathrm{~s}$ in the 3, 7 and 10 min scraping stages.

\subsubsection{X-ray fluorescence analysis}

The sample for the X-ray fluorescence (XRF) analysis was first prepared. Two and a half spatula of boric acid and two spatula of the powder sample were mixed in a beaker. The mixture was poured into the mounting press and moulded at a pressure above 400 bars. The pellet obtained was labelled. The sample was then subjected to XRF analysis. 


\section{RESULTS AND DISCUSSION}

Figure 1 illustrates the grind curve for the Palabora copper ore grinding. The graph obtained is approximately linear indicating that the percentages of the ore passing $75 \mu \mathrm{m}$ generally increased almost linearly with increasing grinding time. At $20 \mathrm{~min}$ grinding, about $45 \%$ of the material passing the $75 \mu \mathrm{m}$ aperture required for flotation was obtained. However, for the froth flotation of the Turkish Corum-Dangaz copper ore ${ }^{6}$ the feed material was ground much finer than the Palabora ore to obtain $90 \%$ passing $75 \mu \mathrm{m}$. It has been reported by Schlanz $z^{7}$ that grinding circuits are the largest power consumers and the most costly to operate accounting for about $50 \%$ of the power supplied to the mills in the United States. The coarser grind of the Palabora ore in this research will thus lead to substantial cost saving in its flotation. ${ }^{7}$

Figures 2 and 3 show the weights of the concentrates obtained in the three-stage scraping (i.e., $\mathrm{C} 1, \mathrm{C} 2, \mathrm{C} 3$ and the total weight, $\mathrm{CT}$ ) and tailings (i.e., T) obtained at different dosages of the SETX collector and scraping time of concentrates. The results obtained indicate that the mass pull into the concentrate generally increased with increasing dosage of SETX collector up to a maximum at $300 \mathrm{~g} / \mathrm{t}$ and then a decrease followed. On the other hand, the tailings weight obtained for the corresponding concentrates decreased with increasing collector dosage down to a minimum at $300 \mathrm{~g} / \mathrm{t}$ dosage and then increased. Furthermore, the grade of the tailings also followed the same pattern with the lowest grade found at $300 \mathrm{~g} / \mathrm{t}$ dosage.

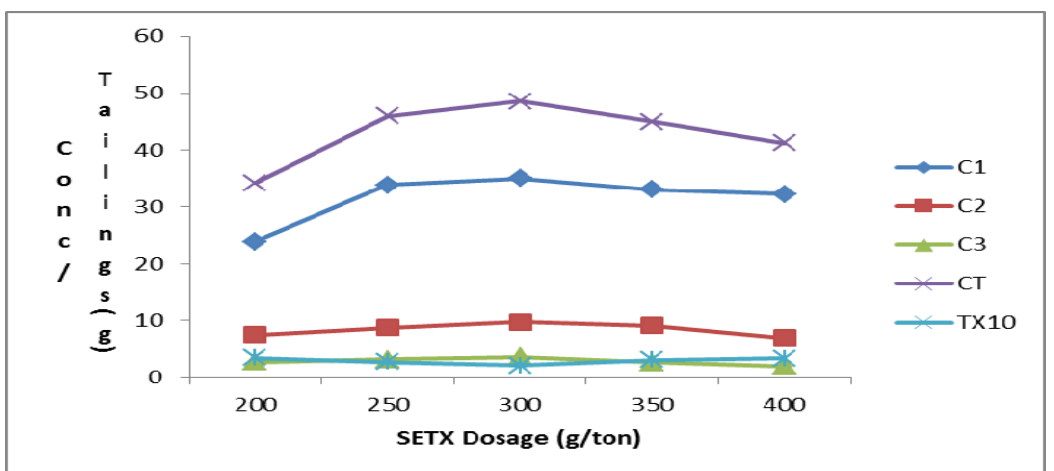

Figure 2: Weights of $\mathrm{Cu}$ concentrate $(\mathrm{C} 1, \mathrm{C} 2, \mathrm{C} 3, \mathrm{CT})$ and tailings (TX10) obtained at varying scraping times and SETX dosages. 


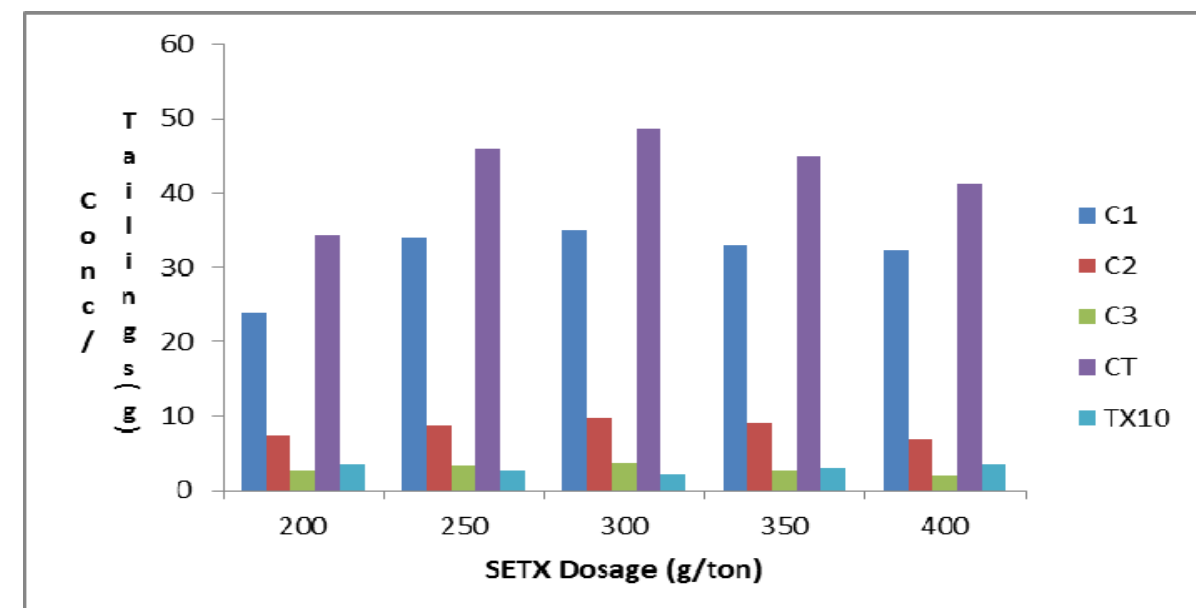

Figure 3: Weights of $\mathrm{Cu}$ concentrate $(\mathrm{C} 1, \mathrm{C} 2, \mathrm{C} 3, \mathrm{CT})$ and tailings (TX10) obtained at varying scraping times and SETX dosages.

The results obtained thus strongly suggest that the optimum dosage of the SETX collector for the flotation of Palabora copper ore is around $300 \mathrm{~g} / \mathrm{t}$. It was further observed that the mass pull into the concentrate was highest in the first concentrate, followed by the second concentrate and was lowest in the third concentrate. Mpongo and Siame ${ }^{8}$ have reported the use of sodium isopropyl xanthate (SIPX) for the flotation of the high grade Zambian Konkola copper ore, consisting of complex mixtures of sulphides and oxide, at initial dosage rate of $140 \mathrm{~g} / \mathrm{t}$ in the ball mills followed by dosing at 10,30, 50 and $80 \mathrm{~g} / \mathrm{t}$ in the froth flotation stage. The total dosage of 150 to $220 \mathrm{~g} / \mathrm{t}$ of sodium isopropyl xanthate used for the Konkola copper ore is lower than the most potent $300 \mathrm{~g} / \mathrm{t}$ dosage of SETX for the carbonatitic Palabora copper ore. These results indicate the need to conduct further studies on the flotation of the Palabora copper with sodium isopropyl xanthate with a view to compare the performance results with that of sodium ethyl xanthate at the same coarse size grind.

Figure 4 shows that the recovery of copper into the concentrate generally increases with increasing dosage of the SETX collector up to maximum of about $86 \%$ at the $300 \mathrm{~g} / \mathrm{t}$ dosage and then a decrease in recovery followed. These results further confirm that the optimal dosage of the SETX collector lies around $300 \mathrm{~g} / \mathrm{t}$. The initial increase in the recovery of copper into the concentrate with increasing collector dosage followed by a decrease might have been due to the alteration in the delicate balance in the capability of bubbles to lift particles in contact with the hydrophobic surface of the copper ore particles and the hydrophilic influence of the surrounding water that tends to cause it to drop the particle beyond the optimal collector dosage. 


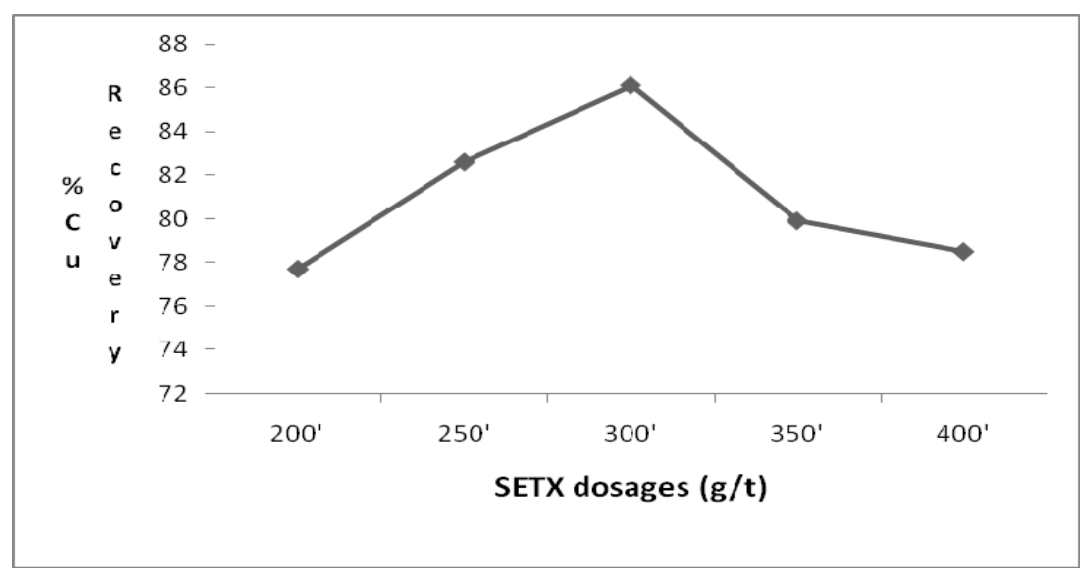

Figure 4: $\mathrm{Cu}$ recovery into concentrates at varying SETX dosages.

Figure 5 shows the relationship between grade/recovery and mass pull percent of the concentrates. The results obtained showed that while recovery $(\mathrm{R})$ naturally increased with mass pull percent, grade $(G)$ decreased. The decrease in grade with increasing mass pull might have been due to the greater probability of gangue being mechanically frothed along with the hydrophobic ore particles with increasing recovery. In Figure 6, the relationship between grade and recovery is presented. The results obtained showed that concentrate grade is inversely proportional to recovery. This observation conforms to the established fact in the froth flotation of ores. ${ }^{4}$

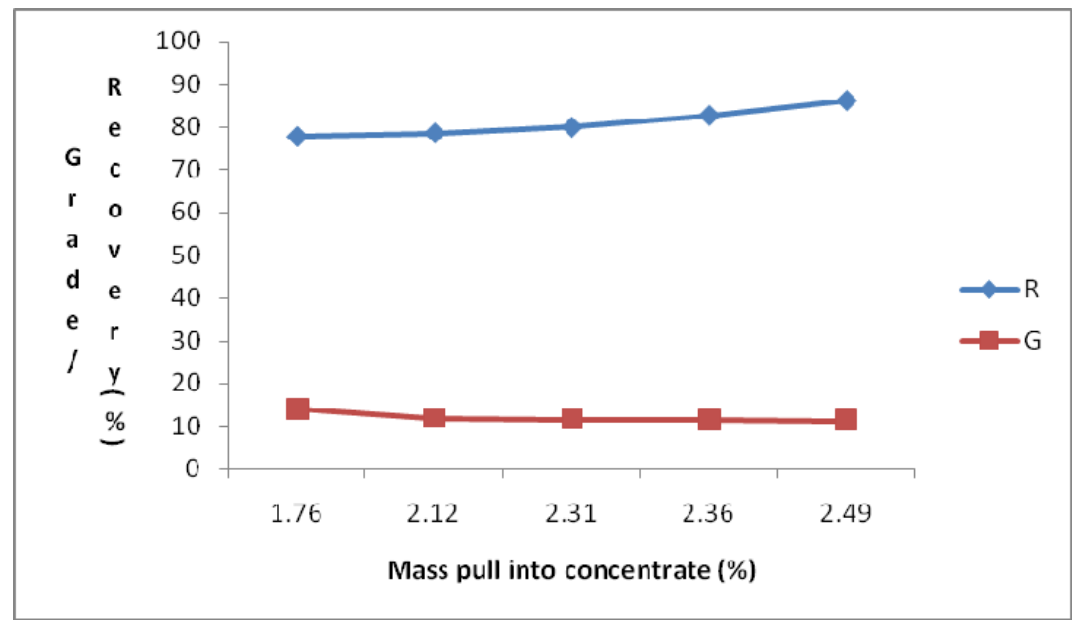

Figure 5: Grade and recovery (\%) at varying mass pull (\%). 


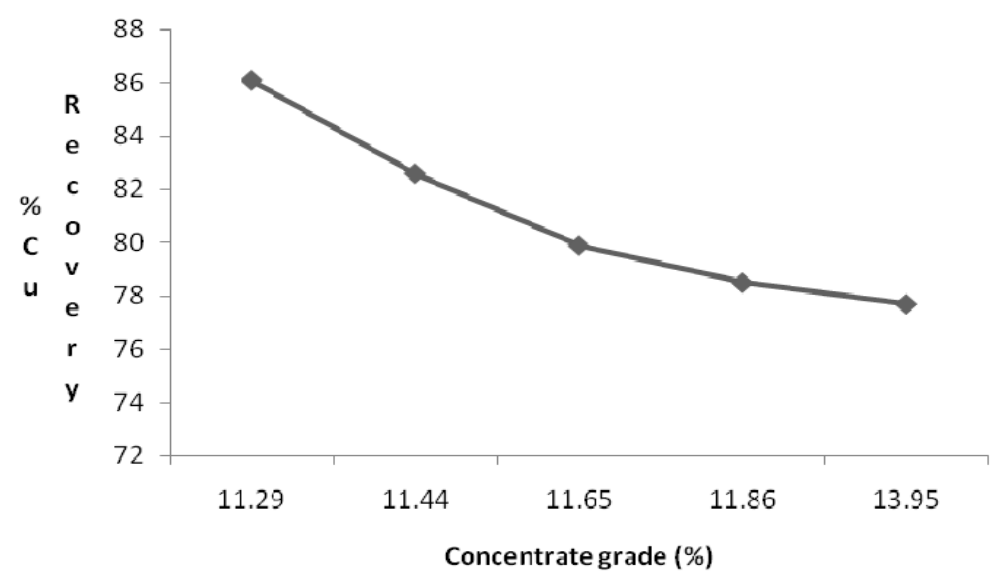

Figure 6: Relationship between recovery and grade of copper in concentrates.

Figure 7 shows that the copper content of the tailings obtained was least at the $300 \mathrm{~g} / \mathrm{t}$ SETX dosage that gave the highest copper recovery. The results thus further confirm the $300 \mathrm{~g} / \mathrm{t}$ dosage as the most potent for the SETX collector used.

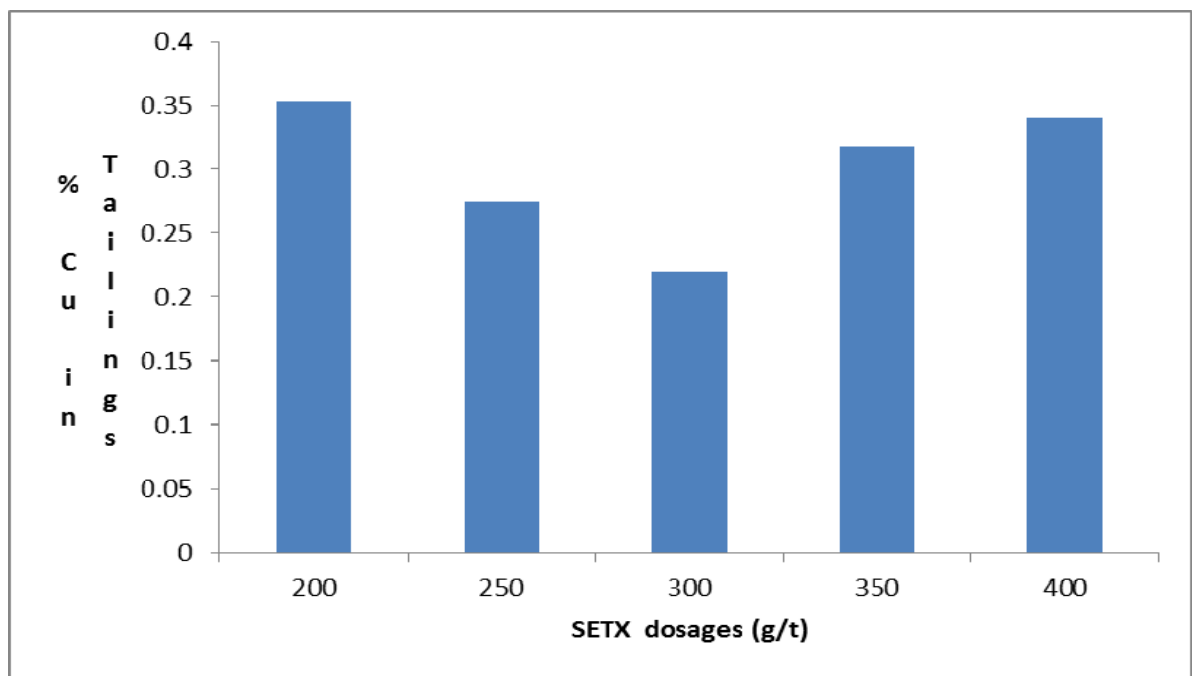

Figure 7: Grade of tailings at varying SETX dosages. 


\section{CONCLUSION}

The carbonatitic Palabora copper ore ground to the relatively coarse $45 \%$ passing $75 \mu \mathrm{m}$ size was successfully concentrated with sodium ethyl xanthate collector instead of the commonly used sodium isopropyl xanthate (SIPX). The results obtained show that the highest recovery of $86.1 \%$ was obtained at the $300 \mathrm{~g} / \mathrm{t}$ SETX dosage with the lowest grade of $11.29 \%$, while the highest grade of $13.95 \%$ occurred at the lowest recovery of about $78 \%$. The dosage of SETX used for the flotation was however found to be higher than that of SIPX for another copper ore of much different chemical composition. The successful flotation of the Palabora ore ground coarser than the conventional practice is however significant economically in view of the potential power conservation to be achieved.

\section{REFERENCES}

1. Davenport, W. G. et al. (2002). Extractive metallurgy of copper. Oxford: Pergamon Press.

2. Palabora Mining Company website. Retrieved from http://www.palabora.com on 8 February 2015.

3. Biswas, A. K. \& Davenport, W. G. (1980). Extractive metallurgy of copper. New York: Pergamon Press.

4. Wills, B. A. \& Napier-Munn, T. (2006). Mineral processing technology. Amsterdam: Elsevier.

5. Tieling Flotation Reagents Company (TFRC). (2004). Retrieved from http://www.minefriend.com/about_en.html on 8 February 2015.

6. Kiraz, E. (2014). Recovery of copper from oxide copper by flotation and leaching. Masters diss., Department of Mining Engineering, Middle East Technical University, Turkey.

7. Schlanz, J. W. (2007). Grinding: An overview of operation and design. Retrieved from http://mrl.ies.ncsu.edu/reports/87-31-P_Grinding _Operations_Design.pdf on 9 March 2013.

8. Mpongo, M. K. \& Siame, E. (2012). Effect of collector, frother and depressant addition on the copper recovery and concentrate grade of the Nchanga underground scavenger circuit of Konkola copper mineZambia. Afr. J. Sci. Technol., 7(1), 8-11. 